\title{
Ocular Adnexal Lymphoma pT1a TNM
} Finding v7

National Cancer Institute

\section{Source}

National Cancer Institute. Ocular Adnexal Lymphoma pT 1a TNM Finding v7. NCI

Thesaurus. Code C88833.

Bulbar conjunctiva only. (from AJCC 7th Ed.) 